Florida International University FIU Digital Commons

$11-3-2009$

\title{
Acoustic Telemetry Studies of Bonefish (Albula vulpes) Movement Around Andros Island, Bahamas: Implications for Species Management
}

Vanessa Haley

Florida International University, haley.vanessa@gmail.com

DOI: $10.25148 /$ etd.FI09121603

Follow this and additional works at: https://digitalcommons.fiu.edu/etd

\section{Recommended Citation}

Haley, Vanessa, "Acoustic Telemetry Studies of Bonefish (Albula vulpes) Movement Around Andros Island, Bahamas: Implications for Species Management" (2009). FIU Electronic Theses and Dissertations. 140.

https://digitalcommons.fiu.edu/etd/140 


\section{FLORIDA INTERNATIONAL UNIVERSITY}

Miami, Florida

ACOUSTIC TELEMETRY STUDIES OF BONEFISH (ALBULA VULPES) MOVEMENT AROUND ANDROS ISLAND, BAHAMAS: IMPLICATIONS FOR SPECIES MANAGEMENT

A thesis submitted in partial fulfillment of the requirements for the degree of MASTER OF SCIENCE in BIOLOGY

by

Vanessa Haley

2009 
To: Dean Kenneth Furton

College of Arts and Sciences

This thesis, written by Vanessa Haley, and entitled Acoustic Telemetry Studies of Bonefish (Albula vulpes) Movement Around Andros Island, Bahamas: Implications for Species Management, having been approved in respect to style and intellectual content, is referred to you for judgment.

We have read this thesis and recommend that it be approved.

Aaron Adams

Timothy Collins

Michael Heithaus

Craig Layman, Major Professor

Date of Defense: November 3, 2009

The thesis of Vanessa Haley is approved.

Dean Kenneth Furton

College of Arts and Sciences

Dean George Walker

University Graduate School

Florida International University, 2009 


\section{DEDICATION}

To my parents, thank you for your encouragement and support over the years. You have given me this wonderful opportunity to live my dream. To my loving brothers, thank you for always finding interest in my work and your willingness to be my field assistant. To Allan T. Benjamin, you have been there through the most trying times. There were moments when I wanted to give up but you motivated me not to only keep trying but to give it my all in fulfillment of my dream. I love you all and without you, the completion of this work would not be possible. 


\section{ACKNOWLEDGMENTS}

I wish to thank the members of my committee for their support and guidance. They challenged my way of thinking and offered suggestions through my research and writing process. Thank you to Liz Wallace from The University of Minnesota for her assistance with the genetic analysis. Although not an official committee member, Dr. Craig Dahlgren has guided me throughout this entire process and I am grateful for his support and advice. From the beginning, my major professor Dr. Craig Layman has had confidence in my abilities to not only complete my degree but also to make a significant contribution to conservation in The Bahamas.

I also would like to thank the members of my lab, particularly Lauren Yeager and Caroline Hammerschlag for their advice, proofreading skills, and friendship throughout my research. I am especially grateful to the staff of Andros Island Bonefish Club, including Shawn Leadon for his fly-fishing skills and knowledge of the field. Other guides such as Andy Smith, Charlie Smith, Prescott Smith, Herman Bain and Clint Kemp have encouraged me and always reminded me of how important my work meant to them. Eric Carey \& Lynn Gape - Bahamas National Trust, Eleanor Phillips - The Nature Conservancy, Minister Earl Deveaux - Ministry of the Environment, Michael Braynen Department of Marine Resources and Debra Erickson - Kerzner Marine Foundation have supported me and on numerous occasions reminded me of how invaluable a qualified Bahamian research scientist will be for my country.

This research was funded by Kerzner Marine Foundation and partially funded by Bonefish Tarpon and Trust. Secondary funding was provided by Florida International University and the National Science Foundation. 


\author{
ABSTRACT OF THE THESIS \\ ACOUSTIC TELEMETRY STUDIES OF BONEFISH (ALBULA VULPES) \\ MOVEMENT AROUND ANDROS ISLAND, BAHAMAS: IMPLICATIONS FOR \\ SPECIES MANAGEMENT \\ by \\ Vanessa Haley
}

Florida International University, 2009

Miami, Florida

Professor Craig Layman, Major Professor

Bonefish (Albula spp.) support an economically important catch-and-release recreational fishery, as well as artisanal harvesting, in The Bahamas. Little is known about the large-scale movement patterns of bonefish, yet such information is essential for proper species conservation and management.

I used acoustic telemetry to determine large-scale movement patterns of bonefish around Andros, Bahamas, in conjunction with presumed spawning migrations. I conclude that bonefish travel long distances from shallow flats to pre-spawning aggregation sites in proximity to off-shore reef locations. Off-shore movement to deeper reef locations occurs around both new and full moons. This study has also confirmed anecdotal reports that the North Bight is an important spawning migration corridor for bonefish.

This information is critical for the protection of bonefish and identifies important habitats (e.g. migration corridors and pre-spawning aggregations) on Andros that warrant protection from coastal degradation or fishing pressures. 


\section{TABLE OF CONTENTS}

CHAPTER

PAGE

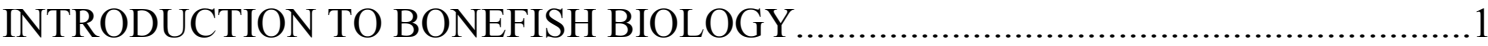

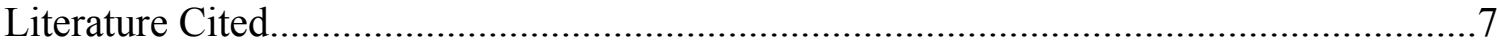

LARGE-SCALE MOVEMENT PATTERNS OF BONEFISH (ALBULA VULPES) AROUND ANDROS ISLAND, BAHAMAS, IN CONJUNCTION WITH PRESUMED SPAWNING MIGRATIONS

Introduction. 10

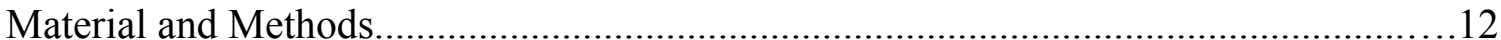

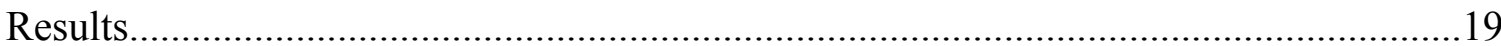

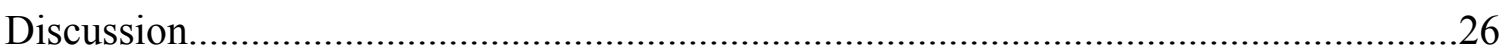

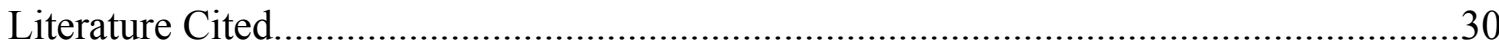

THE FUTURE OF BONEFISH CONSERVATION AND MANAGEMENT IN THE BAHAMAS

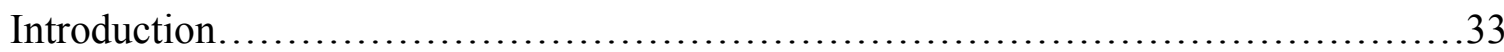

National Park Protection........................................................ 34

Protection Through Fisheries Regulations..........................................

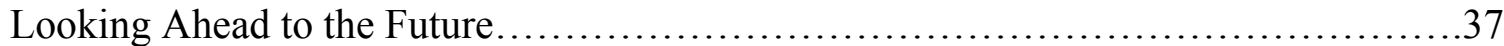

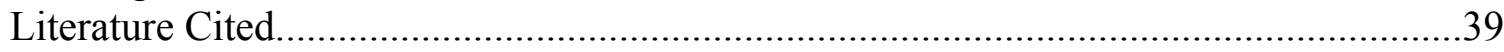




\section{LIST OF FIGURES}

FIGURE

PAGE

1. Tri-phasic life history of bonefish.........................................

2. Location of study Andros, Bahamas.......................................... 12

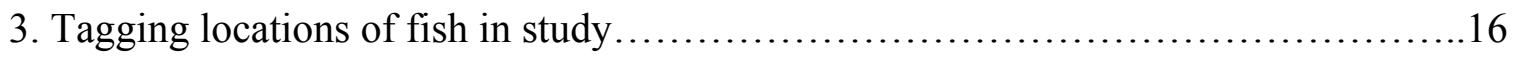

4. Bonefish tagging procedures............................................... 17

5. Location of receivers around Andros, Bahamas................................... 18

6. Bonefish acoustic telemetry results for fish (ID\# 46) in October 2008.................23

7. Bonefish acoustic tag detections on east side receivers..........................25

8. Bonefish acoustic telemetry results for three fish (ID\# 27, $45 \& 46) \ldots \ldots \ldots \ldots \ldots \ldots . \ldots . \ldots$ 


\section{Chapter I}

\section{Introduction to Bonefish (Albula spp.) Biology}

Coastal marine environments are subject to many anthropogenic impacts, including habitat destruction, climate change, pollution and over-fishing (Lotze et al. 2006, Worm et al. 2006). The cumulative effect of these pressures can cause fisheries to decline and ultimately threaten the function of coastal ecosystems (Pauly et al. 2002). Effective management strategies are essential to protect diverse marine resources from degradation, and ensure the livelihood of many human communities which depend on these resources.

Bonefish (Albula spp.) are one such resource. Bonefish are prized by anglers for their fighting ability, and are appropriately called "ghosts of the flats" because of their elusive behavior. Worldwide, bonefish support an important catch-and-release recreational fishery, e.g., contributing about \$1 billion dollars per annum to Florida's economy (Ault et al. 2008), millions of dollars to The Bahamas' economy (Andros Exit Survey Report 2007), and more than \$25 million dollars (sports-fishing for bonefish,

tarpon and permit combined) in direct expenditures for the Belizean economy (Fedler \& Hayes 2008). The economic importance of bonefish for many coastal communities underscores the need to promote a sustainable fishery. Unfortunately, successful management of the fishery is difficult because of large gaps in our understanding of bonefish ecological requirements and life history patterns. 


\section{The Biology and Ecology of Bonefish}

Bonefish have highly conserved morphological and ecological characteristics, despite the divergence of putative species 3 - 30 MYA (Colborn et al. 2001). These uniform features led to the classification of bonefish as a single circumtropical species ( $A$. vulpes - Linnaeus). This idea was challenged with several studies suggesting the presence of cryptic species (Shaklee \& Tamaru 1981, Pfeiler 1996, Colborn et al. 2001) and recent genetic research has identified at least 10 species of bonefish worldwide. Of these, three seem common to the Florida Keys and the Caribbean: A. vulpes, Albula sp. B (popularly known as A. garcia) and A. nemoptera (Crabtree et al. 1996, Colborn et al. 2001). Albula vulpes is believed to be the species that dominates the recreational fishery and is most commonly caught by anglers in Florida (Humston et al. 2005) and possibly The Bahamas (Danylchuk et al. 2007).

Of the three species in the Caribbean, published information has primarily been on A. vulpes and covers age, growth and mortality (Crabtree et al. 1996, Adams et al. 2008); maturation and reproduction (Crabtree et al. 1997); habitat use (Adams et al. 2008); diet (Colton \& Alevizon 1983a, Crabtree et al. 1998); movement (Colton \& Alevizon 1983b, Humston et al. 2005, Larkin et al. 2008); larval duration and temporal abundance patterns (Mojica et al. 1995, Dahlgren et al. 2008); or a combination of these (Bruger 1974, Ault et al. 2008). However, most of these studies were conducted before the identification of Albula sp. B by Colborn et al. (2001). Therefore, additional research is required to verify these findings, and explore how ecological traits may vary among species or regions. 
For example, studies have revealed variation in growth rates for $A$. vulpes among Florida, the Western Atlantic, and the Caribbean (Crabtree et al. 1996, Adams et al. 2008). Compared to the rest of the Caribbean and Western Atlantic, Florida bonefish appear to be growing faster and reach larger sizes (Ault et al. 2007). An 8 year-old bonefish in Florida measures, on average, $609 \mathrm{~mm}$ (FL) (Crabtree et al. 1997) whereas in the Caribbean, it measures $406 \mathrm{~mm}$ (FL) (Adams et al. 2008). These regional variations in growth provide an example of why it is an over-simplification to make generalizations about the population dynamics of bonefish throughout their range. There is a clear need to reassess our current understanding of bonefish biology and ecology in the Caribbean, especially in areas where few studies have been conducted to this point, e.g. throughout the Bahamian archipelago.

\section{Bonefish Reproduction}

Bonefish undergo ontogenetic habitat shifts, occupying several habitats through their life history. It is presumed that bonefish (Albula spp.) exhibit a tri-phasic life history strategy, occupying several habitats throughout their life history (Humston et al. 2005, Ault et al. 2008, Larkin et al. 2008), which is quite common for many aquatic species (Fairweather 1991). Animals with this life history strategy exhibit three key phases of ontogeny, movement and resource use (Fig. 1): (1) the planktonic movement of eggs and larvae; (2) juvenile and sub-adult use of shallow water areas; and (3) an offshore movement to deeper water, usually coinciding with the onset of maturity (Pittman \& McAlpine 2003). 


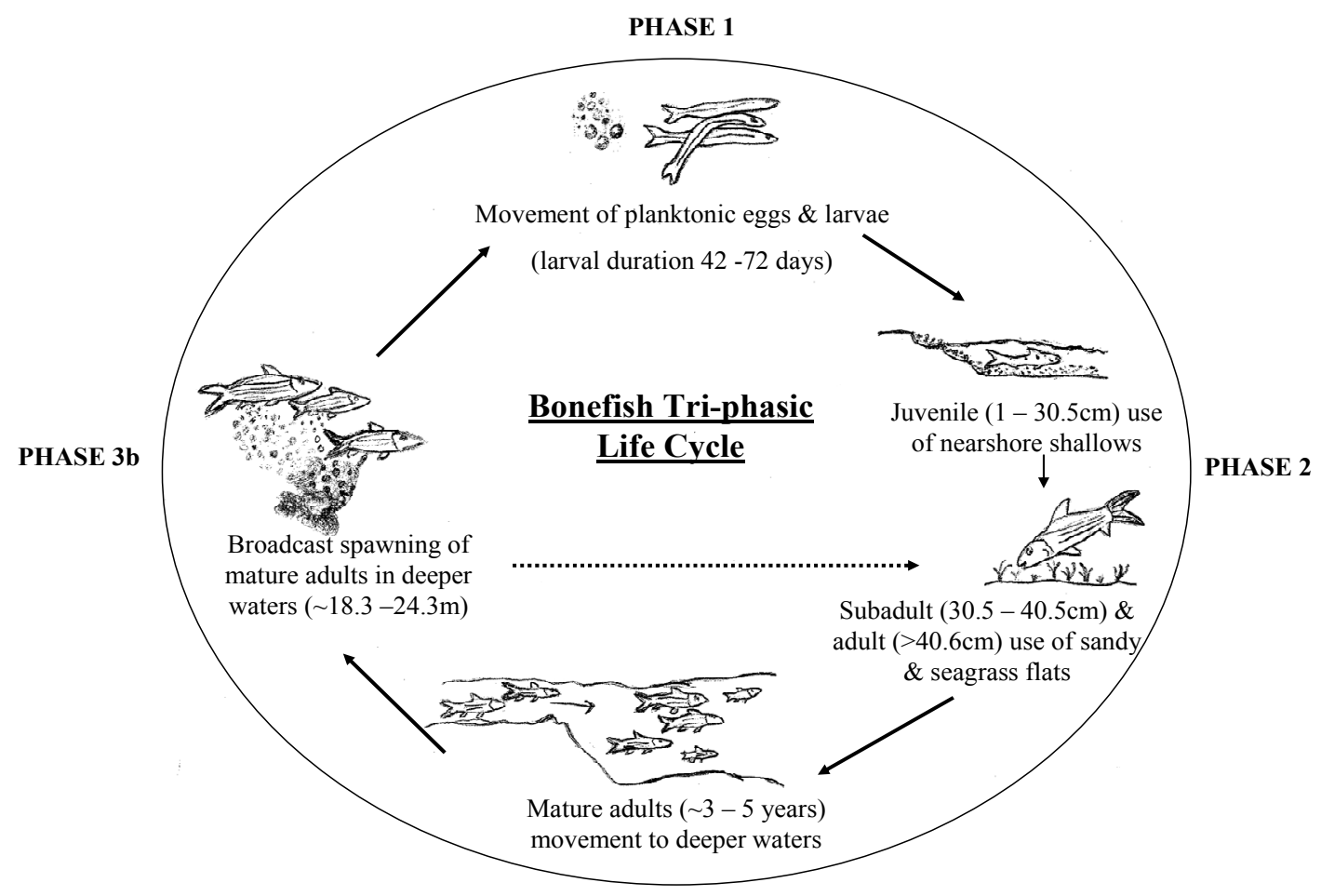

FIGURE 1: Presumed tri-phasic life history strategy of bonefish (adapted from Pittman \& McAlpine, 2001). The model shows discrete phases of development and movement. Phase 1: the planktonic movement of eggs and larvae, Phase 2: juvenile and sub-adult use of shallow water areas, and Phase 3: an offshore movement to deeper waters to spawn.

Once bonefish migrate from shallow to deeper water (presumed to be near reef slopes), they undergo "broadcast spawning", i.e., males and females release gametes into the water column allowing for external fertilization of eggs. Eggs hatch within one day, producing small leptocephalus larvae that float in the open ocean, living as plankton for 42 - 72 days (Pfeiler 1988, Mojica et al. 1995). In the Florida Keys, in conjunction with the new or full moon, larvae of $A$. vulpes move into shallow habitats throughout the spring before metamorphosing into juvenile stages (Crabtree et al. 1997). Larval sampling on Lee Stocking Island, Bahamas, resulted in highest numbers of bonefish December - June (Thorrold et al. 1994, Mojica et al. 1995, Dahlgren et al. 2008). 
Although we have a general understanding of the presumed life history strategies of bonefish, there still remain significant knowledge gaps. For example, the juvenile habitats of bonefish (mainly A. vulpes) remain unknown. However, preliminary studies reveal that juveniles of $A$. garcia may occupy sandy beaches (Adams, personal communication), with sub-adults occupying back-water tidal creeks. Mature adults primarily utilize shallow tidal flats as foraging grounds (Adams 2006) but studies on larval dispersal and settlement (Mojica et al. 1995, Dahlgren et al. 2008) suggest that bonefish migrate to reef slopes in large aggregations to spawn. However, such large-scale movements to offshore spawning aggregations, along with the duration or frequency of these events, have never been documented in the scientific literature. In addition, there is little information regarding regional variation or species-specific differences in spawning patterns.

This thesis will provide an overview of the large-scale movements of bonefish (Albula spp.) around Andros, Bahamas and determine: (1) identification of bonefish species in the recreational fishery using microsatellite analysis; (2) if adult bonefish migrate to offshore reefs during the proposed spawning season and, if so, to determine the frequency of these large-scale movements; (3) if these movements are predictable and follow lunar cycles. The concluding chapter will discuss the significance of this information with respect to the future of bonefish conservation and management in The Bahamas.

This study is the first aimed at addressing specific questions regarding the spawning movements of $A$. vulpes in The Bahamas. This research may substantiate the inclusion of pre-spawning and spawning sites in the design of a proposed Marine 
Protected Area (MPA) on the West Side of Andros or the creation of fishing regulations (such as closed seasons) during spawning periods. Broader significance of this study includes filling critical knowledge gaps in our understanding of bonefish spatial ecology, population biology, conservation and management. 


\section{LITERATURE CITED}

Adams, A.J. 2006. Rapid Ecological Assessment West Coast of Andros, The Bahamas: Preliminary report of scientific findings, The Nature Conservancy, Nassau, Bahamas.

Adams, A.J., R.K. Wolfe, M.D. Tringali, E.M. Wallace \& G.T. Kellison. 2008. Rethinking the status of Albula spp. biology in the Caribbean and Western Atlantic. pp. 203-214. In: J.S. Ault (ed.) Biology and management of the world tarpon and bonefish fisheries, CRC Press, Boca Raton, FL.

Andros Exit Survey Report. 2007.pp. 42, Ministry of Tourism, Nassau.

Ault, J.S., R. Humston, M.F. Larkin, E. Perusquia, N.A. Farmer, J. Luo, N. Zurcher, S.G. Smith, L.R. Barbieri \& J.M. Posada. 2008a. Population dynamics and resource ecology of Atlantic tarpon and bonefish. pp. 217-258. In: J.S. Ault (ed.) Biology and management of the world tarpon and bonefish fisheries, CRC Press, Boca Raton, FL.

Ault, J.S., S. Moret, J. Luo, M.F. Larkin, N. Zurcher \& S.G. Smith. 2008b. Florida Keys bonefish population census. pp. 383-398. In: J.S. Ault (ed.) Biology and management of the world tarpon and bonefish fisheries, CRC Press, Boca Raton, FL.

Bruger, G.E. 1974. Age, growth, food habits, and reproduction of bonefish Albula vulpes in South Florida waters. 20.

Colborn, J., R.E. Crabtree, J.B. Shaklee, E. Pfeiler \& B.W. Bowen. 2001. The evolutionary enigma of bonefishes (Albula spp.): Cryptic species and ancient separations in a globally distributed shorefish. Evolution 55: 807-820.

Colton, D.E. \& W.S. Alevizon. 1983a. Feeding ecology of bonefish in Bahamian waters. Transactions of the American Fisheries Society 112: 178-184.

Colton, D.E. \& W.S. Alevizon. 1983b. Movement patterns of bonefish, Albula vulpes, in Bahamian waters. Fishery Bulletin 81: 148-154.

Crabtree, R.E., C.W. Harnden, D. Snodgrass \& C. Stevens. 1996. Age, growth, and mortality of bonefish, Albula vulpes, from the waters of the Florida Keys. Fishery Bulletin 94: 442-451.

Crabtree, R.E., D. Snodgrass \& C.W. Harnden. 1997. Maturation and reproductive seasonality in bonefish, Albula vulpes, from the waters of the Florida Keys. Fishery Bulletin 95: 456-465. 
Crabtree, R.E., C. Stevens, D. Snodgrass \& F.J. Stengard. 1998. Feeding habits of bonefish, Albula vulpes, from the waters of the Florida Keys. Fishery Bulletin 96: 754-766.

Dahlgren, C., J.M. Shenker \& R. Mojica. 2008. Ecology of bonefish during the transition from late larvae to early juveniles. pp. 155-177. In: J.S. Ault (ed.) Biology and management of the world tarpon and bonefish fisheries, CRC Press, Boca Raton, FL.

Danylchuk, A.J., S.E. Danylchuk, S.J. Cooke, T.L. Goldberg, J.B. Koppelman \& D.P. Philipp. 2007. Post-release mortality of bonefish, Albula vulpes, exposed to different handling practices during catch-and-release angling in Eleuthera, The Bahamas. Fisheries Management and Ecology 14: 149-154.

Fairweather, P.G. 1991. Implications of Supply-Side Ecology for Environmental Assessment and Management. Trends in Ecology \& Evolution 6: 60-63.

Fedler, A.J. \& C. Hayes. 2008. Economic Impact of Recreational Fishing for Bonefish, Permit and Tarpon in Belize for 2007.

Humston, R., J.S. Ault, M.F. Larkin \& J.G. Luo. 2005. Movements and site fidelity of the bonefish Albula vulpes in the northern Florida Keys determined by acoustic telemetry. Marine Ecology-Progress Series 291: 237-248.

Larkin, M.F., J.S. Ault, R. Humston, J. Luo \& N. Zurcher. 2008. Tagging of Bonefish in South Florida to Study Population Movements and Stock Dynamics. In: J.S. Ault (ed.) Biology and Management of the World Tarpon and Bonefish Fisheries, CRC Press, Boca Raton, FL.

Lotze, H.K., H.S. Lenihan, B.J. Bourque, R.H. Bradbury, R.G. Cooke, M.C. Kay, S.M. Kidwell, M.X. Kirby, C.H. Peterson \& J.B.C. Jackson. 2006. Depletion, degradation, and recovery potential of estuaries and coastal seas. Science 312: 1806-1809.

Mojica, R., J.M. Shenker, C.W. Harnden \& D.E. Wagner. 1995. Recruitment of bonefish, Albula vulpes, around Lee Stocking Island, Bahamas. Fishery Bulletin 93: 666674.

Pauly, D., V. Christensen, S. Guenette, T.J. Pitcher, U.R. Sumaila, C.J. Walters, R. Watson \& D. Zeller. 2002. Towards sustainability in world fisheries. Nature 418: 689-695.

Pfeiler, E. 1988. Isolation and Partial Characterization of a Novel Keratan Sulfate Proteoglycan from Metamorphosing Bonefish (Albula) Larvae. Fish Physiology and Biochemistry 4: 175-187. 
Pfeiler, E. 1996. Allozyme differences in Caribbean and Gulf of California populations of bonefishes (Albula). Copeia: 181-183.

Pittman, S.J. \& C.A. McAlpine. 2003. Movement of Marine Fish and Decapod Crustaceans: Process, Theory and Application. Advances in Marine Biology: 205294.

Shaklee, J.B. \& C.S. Tamaru. 1981. Biochemical and Morphological Evolution of Hawaiian Bonefishes (Albula). Systematic Zoology 30: 125-146.

Thorrold, S.R., J.M. Shenker, R. Mojica, E.D. Maddox \& E. Wishinski. 1994. Temporal patterns in the larval supply of summer recruiting reef fishes to Lee Stocking Island, Bahamas. Marine Ecology-Progress Series 112: 75-86.

Worm, B., E.B. Barbier, N. Beaumont, J.E. Duffy, C. Folke, B.S. Halpern, J.B.C. Jackson, H.K. Lotze, F. Micheli, S.R. Palumbi, E. Sala, K.A. Selkoe, J.J. Stachowicz \& R. Watson. 2006. Impacts of biodiversity loss on ocean ecosystem services. Science 314: 787-790. 


\section{Chapter II}

\section{Large-scale Movement Patterns of Bonefish (Albula vulpes) Around Andros Island, Bahamas, in Conjunction with Presumed Spawning Migrations}

\section{INTRODUCTION}

Animal movement ultimately determines the spatial, demographic and genetic structure of populations (Pittman \& McAlpine 2003). Marine fish exhibit a wide range of movements that can be broadly categorized into five types: (1) pelagic movement of eggs and larvae; (2) daily home range movements at a given life history stage; (3) ontogenetic habitat shifts; (4) relocation of home ranges in response to abiotic and biotic patterns, including human activities and; (5) large-scale migrations, often for spawning purposes (Johannes 1978, Morgan \& Christy 1994). These movements occur at different spatial and temporal scales and may follow predictable patterns, for instance, according to daily, tidal, lunar or seasonal cycles (Norcross \& Shaw 1984, Morgan \& Christy 1994, Botsford et al. 2001).

From an applied perspective, understanding animal movement patterns in time and space is fundamental to the design of effective conservation and resource management strategies (Acosta 1999, Warner et al. 2000, Pittman \& McAlpine 2003). Most theoretical and conceptual investigations into Marine Protected Area (MPA) design have focused on determining the optimal size or spatial arrangement of MPA's (Rapid Ecological Assessment West Coast of Andros 2006). However, it is equally important to understand specific movement patterns of key species and link this to which habitat types or key areas (e.g. essential nursery areas or spawning areas) are necessary to include in 
MPA design (Botsford et al. 2001). In the case of highly mobile species, unless MPA's are large enough to include all habitats and migration corridors of key species, MPA's will only offer protection on a partial or seasonal basis (Afonso et al. 2009). But if MPA's were to include important spawning sites and corridors, they still could play a vital role in fishery management (Kramer \& Chapman 1999, Roberts \& Sargant 2002, Afonso et al. 2009).

Bonefish are a circumtropical species that inhabit shallow coastal waters and near-shore reefs. Despite its popularity and economic importance as a primarily catchand-release fishery, there still remain significant gaps in our understanding of bonefish reproductive ecology. And with up to ten species worldwide (Colborn et al. 2001, Bowen 2008, Pfeiler 2008), and possible intra-specific differences in life history patterns among regions (Adams et al. 2008), much additional research is needed.

In the current study, data is presented on the seasonal large-scale movement of Albula spp. around Andros, Bahamas obtained through the use of acoustic telemetry. Specifically, this study was designed to determine: (1) identification of bonefish species in the recreational fishery using microsatellite analysis; (2) if adult bonefish migrate to offshore reefs during the proposed spawning season and, if so, to determine the frequency of these large-scale movements; (3) if these movements are predictable and follow lunar cycles. 


\section{MATERIALS \& METHODS}

\section{Study Site}

Andros is located approximately $100 \mathrm{~km}$ southeast of the southern tip of Florida. The eastern side of Andros is bordered by a deep oceanic trench, called the Tongue of the Ocean and drops to a depth of approximately $1.8 \mathrm{~km}$. (Fig 2). A fringing barrier reef, the third largest in the world, runs along the Tongue of the Ocean for approximately $225 \mathrm{~km}$.

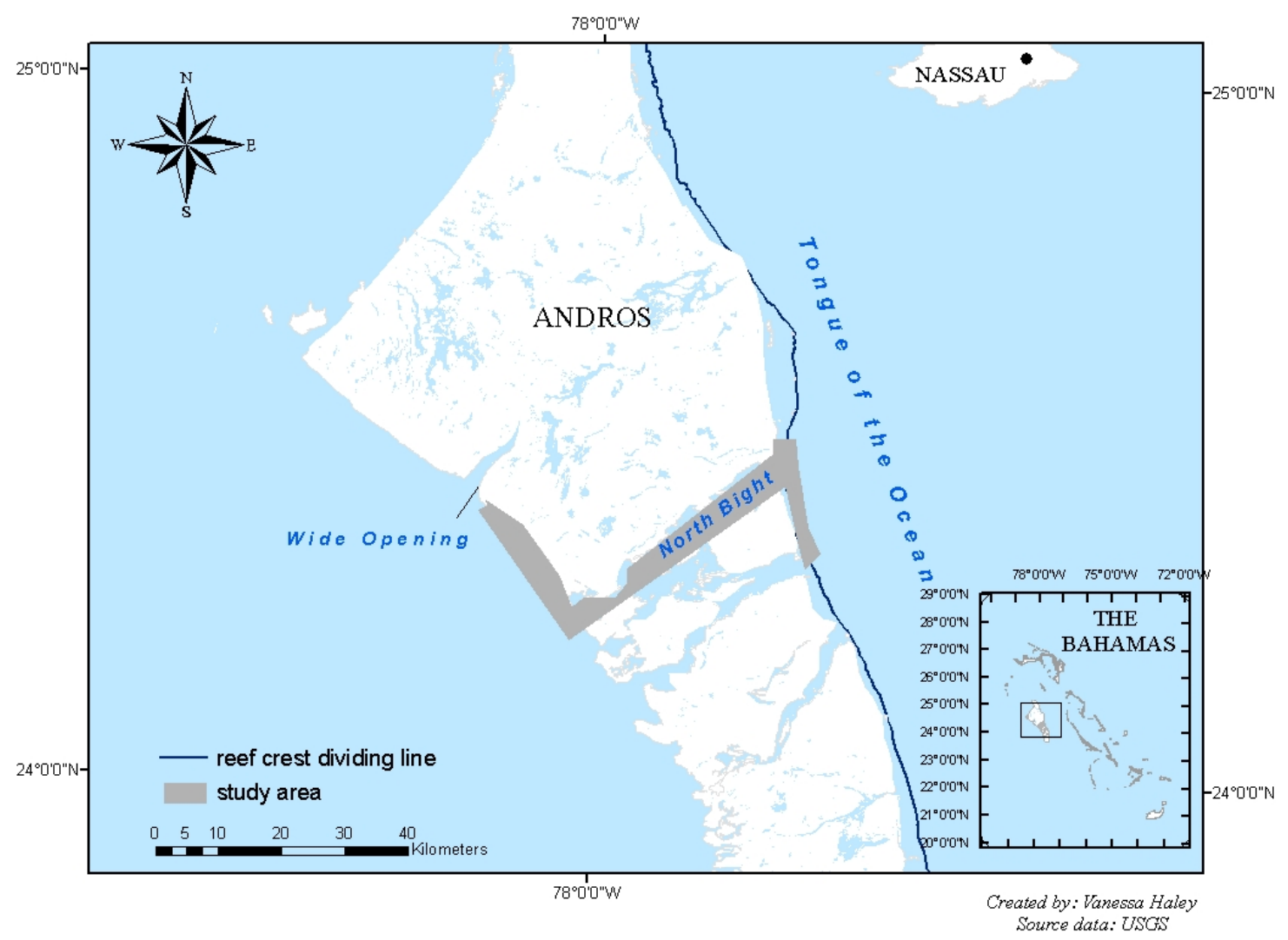

FIGURE 2: Location of study, Andros Island, Bahamas.

Located on the eastern margin of the Great Bahama Bank, west Andros is a low energy setting, dominated by mangrove-lined creeks and sounds, with abundant lowlying carbonate islands, tidal flats, tidal creeks, brackish lagoons, and seagrass beds along 
with sponge-dominated hard bottoms (Ray \& McCormick 2004, Humston et al. 2005, Rapid Ecological Assessment West Coast of Andros 2006).

Western Andros may be the most pristine coastal area in the entire Caribbean region (Rapid Ecological Assessment West Coast of Andros 2006). While there are some areas of western Andros used by humans, most of the area lacks permanent human presence and it is infrequently visited. The area is ideally suited for creating a protected area to preserve the marine environment in a near pristine condition. Much of west Andros consists of shallow tidal flats frequented by anglers. This area has been referred to by many fly-fishing magazines as the "bonefishing capital of the world". Although bonefish primarily support a catch-and-release fishery, a small-scale subsistence fishery exists as well. This study was conducted within northern bight and along the western and eastern side of Andros (Fig. 2). Field work commenced in October 2008 and continued through August 2009.

\section{Species Identification}

To determine species identification, tissue samples were taken from bonefish within the study area. A triangle (12 mm x $12 \mathrm{~mm} \times 12 \mathrm{~mm})$ was cut from the soft ray tissue at the rear of the dorsal fin. Purified genomic DNA from collected tissue samples of tagged bonefish was isolated using the Puregene ${ }^{\circledR}$ isolation kit (Qiagen, Inc., Valencia, California) following methods described in Adams et al. (2008). Collaborators from the University of Minnesota have developed a bonefish specific microsatellite library through a slightly modified protocol described by Seyoum et al. (2008) and PCR-based isolation

of the microsatellite arrays was carried out as described in Lunt et al. (1999). The library, 
including loci that were recently developed, consists of 19 polymorphic loci capable of distinguishing discrete species of bonefish found in the Caribbean as well as hybrids. Multiplex microsatellite screening PCR assays was performed on Eppendorf $f^{\circledR}$ thermal cyclers under standardized run conditions (Elizabeth Wallace, personal communication).. Allelic data were obtained on an Applied Biosystems genetic analyzer, and scored in Genemapper ${ }^{\circledR}$.

\section{Equipment and Range Testing}

Coded acoustic transmitters, VEMCO Model V13-1L (147 dB), along with VEMCO Model VR-2 receivers and a manual tracking hydrophone was used to monitor bonefish movements. Tag transmissions were separated by $30-80 \mathrm{~s}$ (random) delays, providing battery life of at least 570 days post activation. To determine the range that a receiver can detect a transmitter, an activated transmitter was towed $(6 \mathrm{~cm}$ from substrate because bonefish are typically bottom-oriented) in a predetermined pattern around selected receiver stations. Results of range testing of AT-tags by hydrophone receivers revealed that detections were highly variable depending upon depth, current, tidal flow along with wind direction and velocity. As a result, detection ranges by shallow water receivers $(<1 \mathrm{~m}$ depth) ranged from $20-40 \mathrm{~m}$. Detection ranges of $250-500 \mathrm{~m}$ were recorded in deeper waters ( $>2 \mathrm{~m}$ depth). 


\section{Capture and Tagging Methods}

During October 2008 - January 2009, twenty-five adult bonefish, ranging in size from 358 - $548 \mathrm{~mm}$ fork length (FL) were caught using fly-fishing gear by professional guides and were surgically implanted with acoustic transmitters. Studies revealed that bonefish in the Florida Keys, reach 50\% sexual maturity at $488 \mathrm{~mm}$ fork length or $1.8 \mathrm{~kg}$ (Crabtree et al. 1997, Ault et al. 2008). Where possible, $1.8 \mathrm{~kg}$ to $2.7 \mathrm{~kg}$ size bonefish were chosen to maximize the potential of capturing and tagging fish that were likely to spawn (i.e., sexually mature males and females). Observed fish were tagged from locations around Andros where bonefish are known to congregate. These included areas on the west side (e.g., at Wide Opening), within North Bight and on the east side (near the Behring Point, AUTEC base) (Fig. 3). 


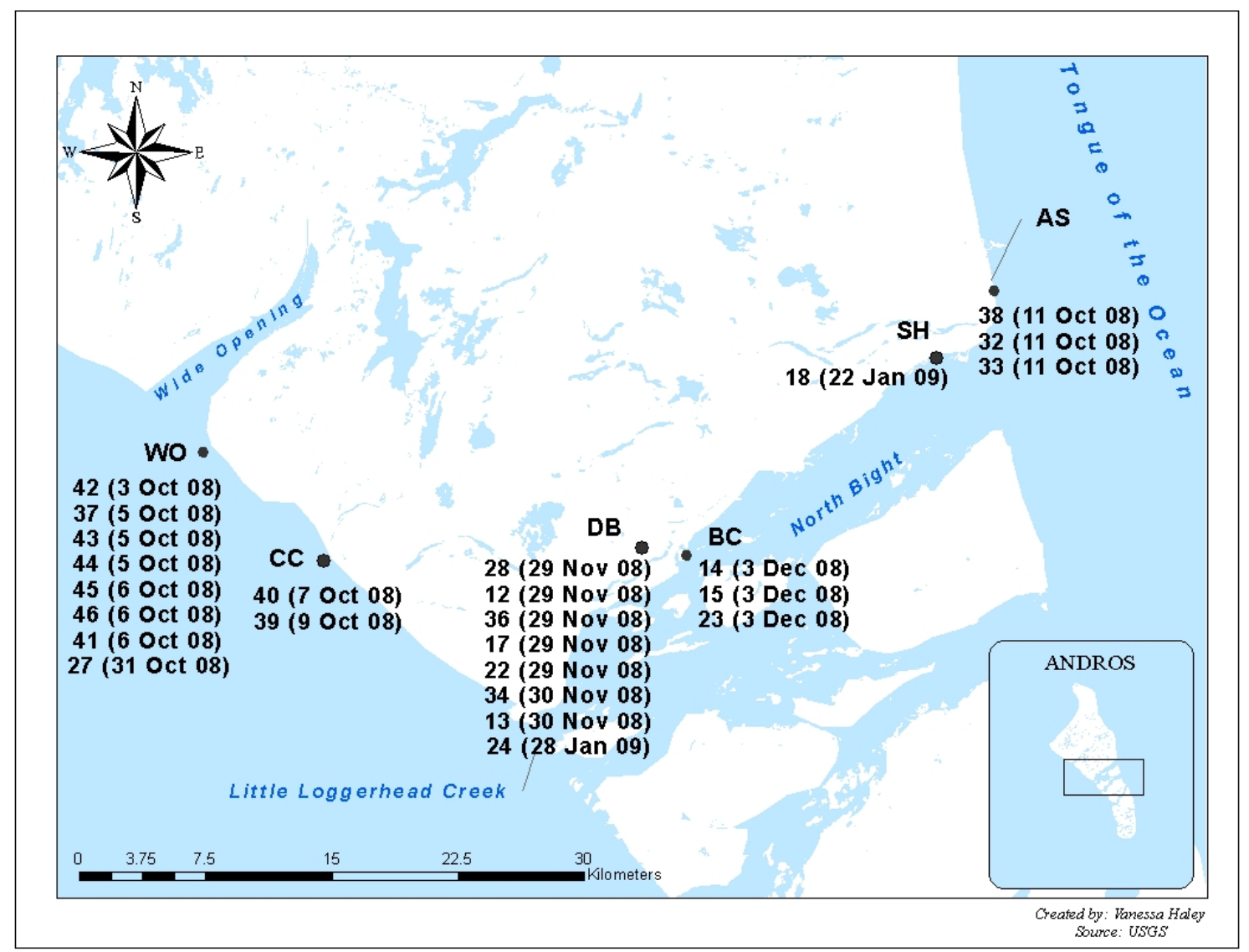

FIGURE 3: Release locations and dates of AT-tagged bonefish around Andros Island, Bahamas. Location codes: WO (Wide Opening), CC (Cabbage Creek), DB (Diamond Bay), BC (Black Creek), SH (Spice Harbor), AS (AUTEC Shallow).

Following capture, fish were anesthetized with MS-222 and placed ventral-side up on a surgery table. The bonefish was secured on the surgery table and fresh seawater was circulated through the mouth and over the gills during surgery. The acoustic tags, measuring $36 \mathrm{~mm}$ long and $13 \mathrm{~mm}$ in diameter, were surgically implanted through an approximate $2 \mathrm{~cm}$ incision into the peritoneal cavity of the bonefish using field procedures similar to those described in Humston et al. (2005) and following FIU Institutional Animal Care and Use Committee (IACUC) protocols (Fig. 4). Incisions were closed using Ethicon monofilament sutures. Fish were allowed to recover in an onboard 
holding tank immediately following surgery. Times of recovery varied with each fish depending on size and fighting time. However, average recovery time was typically 5 minutes. $92 \%$ of fish recovered following surgery. Once recovered, fish were released at the capture location. Along with implanting the acoustic transmitters, bonefish were measured (FL) and a fin clip was taken from the rear dorsal fin for genetic analysis. In addition, any sign of sexual maturity (i.e. presence of eggs or milting) was recorded.
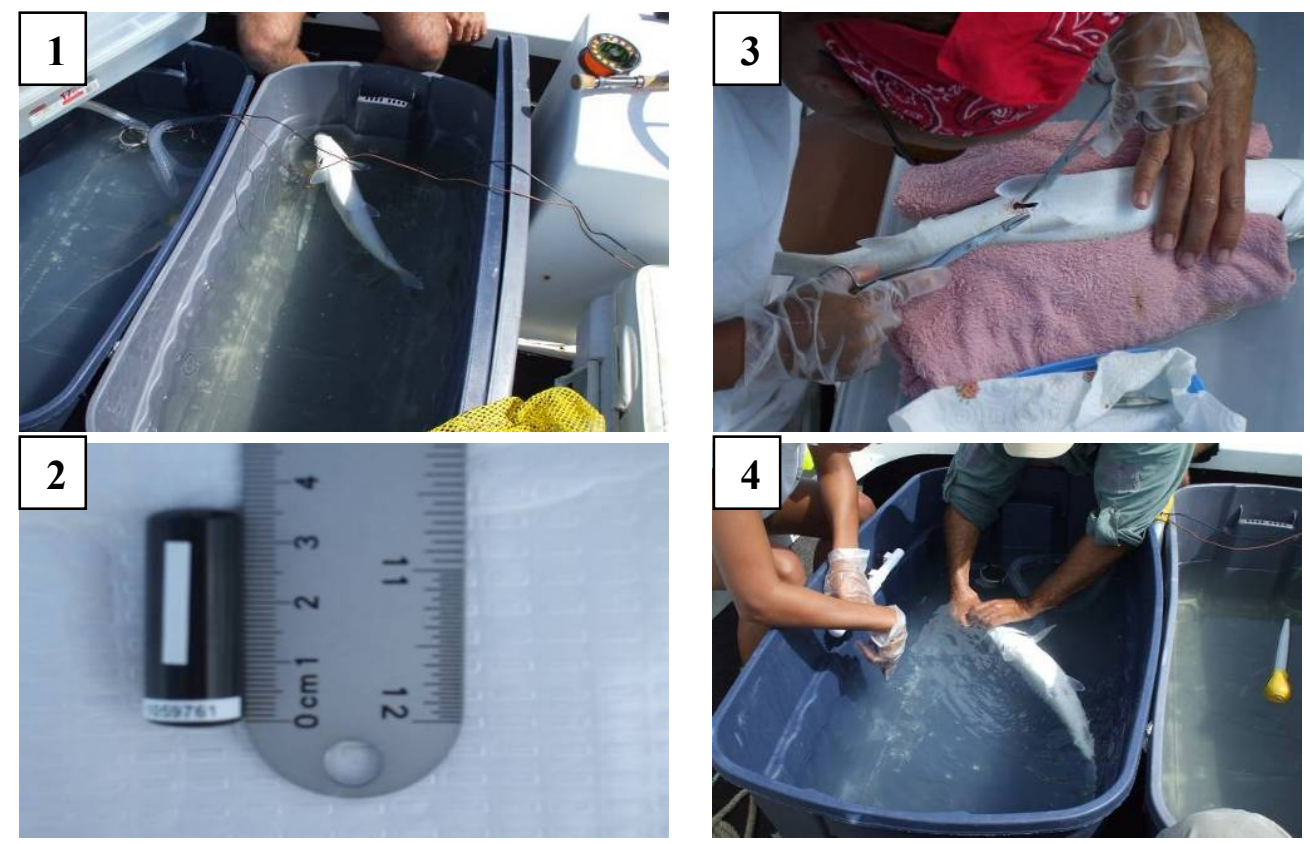

FIGURE 4: Bonefish tagging procedures; (1) fish are anesthetized in a large aerated tub;

(2) an acoustic telemetry transmitter inserted in the abdomen through a small incision;

(3) incision closed with a medical suture; (4) fish allowed to recover before release.

\section{Receiver Deployment}

Prior to transmitter deployment, twenty-seven VEMCO (www.vemco.com) VR2 receivers were deployed around Andros at depths ranging from $0.6-20 \mathrm{~m}$. Receivers were placed in areas to maximize the likelihood of detecting tagged fish, i.e., in deep channels between islands where bonefish are frequently sighted. These areas included 
channels within Middle and North Bight, along the shallow flats on the west side and near the reef slope on the east side (Fig. 5).

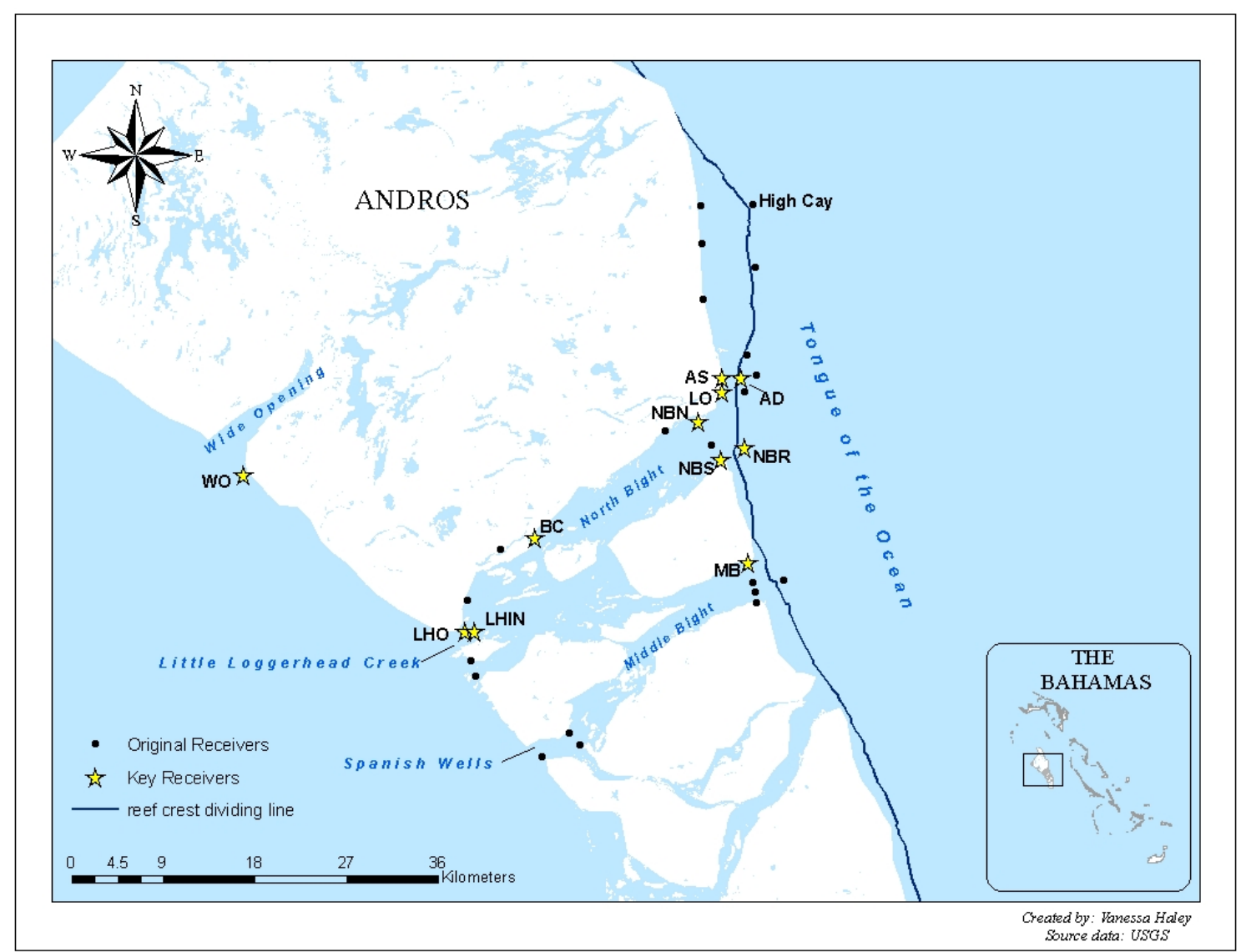

FIGURE 5: Map of Andros Island, Bahamas. Location of receivers, identified by stars, that detected tagged fish. Closed circles indicate locations of original receivers in array. Original receivers were adjusted after receiving no detections. WO - (Wide Opening), LHO - (Little Loggerhead Creek In), LHIN - (Little Loggerhead Creek Out), BC - (Black Creek), NBN - (North Bight North), NBS (North Bight South), NBR - (North Bight Reef), LO - (Lodge), AS - (AUTEC Shallow), AD (AUTEC Deep), MB - (Middle Bight).

Two receivers were placed per channel to ensure the entire width of the channel was covered and to increase the likelihood of detecting the direction of migration. The southern most receivers were pulled after no detections following two consecutive downloads in October and November 2009. The receivers were repositioned within North Bight where most movement was detected to provide additional data on movements 
within in this frequently traveled area. In addition, receivers were also repositioned near reef slopes ( $\sim 6 \mathrm{~m}$ depth) that received prior hits and were assumed to be either a pre/spawning aggregation site or a major movement corridor (Fig. 5).

\section{RESULTS}

A total of 70 bonefish fin clips, including telemetry tagged fish and additional samples provided by anglers, were identified as Albula vulpes. Past studies on the species composition of bonefish within the recreational fishery detected a second species (Albula sp. B) after a total of approximately 1,400 samples (Aaron Adams, personal communication). These sampling patterns, suggests the rarity of a multi-species recreational fishery and suggests possible habitat differentiation among species. Since all fish were A. vulpes, no species-specific analysis pertaining to movement patterns was warranted.

Sequential Bonferroni corrections (Rice 1989) were applied to test the initial set of samples (collected in Florida) used to create and assess the microsatellite library. There were no significant departures from Hardy-Weinberg equilibrium expectations (table-wide $\alpha=0.05$ ) nor evidence of nonrandom association between alleles at any locus pair (Seyoum et al. 2008). The microsatellite data were analyzed in GENETIX, a three dimensional cluster analysis (Belkhir et al. 2000). The samples collected in this study were compared against the genotypes of known specimens of $A$. vulpes, $A$. sp. $B$ (also known as $A$. garcia), and $A$. sp. cf. vulpes.

Number of alleles, observed and expected heterozygosities and genotypic equilibrium were assessed using GENEPOP version 4.0 (http://genepop.curtin.edu.au/) 
for the 70 fish sampled in this study (Raymond and Rousset 1995). The average number of alleles per locus was 6.7 , mean observed heterozygosity was 0.34 , and average expected heterozygosity was 0.44 (Table 1). There was evidence of non-random association between alleles at locus pair AspB003 and AspB005 $(\mathrm{p}=0.002)$.

TABLE 1: Characterization of 17 microsatellite loci for the bonefish (Albula sp.). *Number of alleles; $H_{\mathrm{O}}$, observed heterozygosity; $H_{\mathrm{E}}$, expected heterozygosity; NS, not submitted.

\begin{tabular}{cccccc}
\hline Locus & $\mathbf{k}^{*}$ & $\begin{array}{c}\text { Allele size } \\
\text { range }\end{array}$ & $\mathbf{H}_{\mathbf{O}}$ & $\mathbf{H}_{\mathbf{E}}$ & $\begin{array}{c}\text { GenBank } \\
\text { Accession } \\
\text { Number }\end{array}$ \\
\hline Avu01 & 9 & $200-227$ & 0.50 & 0.77 & DQ869248 \\
Avu02 & 2 & $141-142$ & 0 & 0.93 & DQ869249 \\
Avu04 & 1 & $214-216$ & 0.03 & 0.03 & DQ869250 \\
Avu11 & 4 & $155-161$ & 0.7 & 0.62 & DQ869252 \\
Avu12 & 2 & $180-182$ & 0.17 & 0.15 & DQ869253 \\
Avu14 & 3 & $129-131$ & 0.10 & 0.10 & DQ869255 \\
Avu16 & 2 & $112-114$ & 0.12 & 0.16 & DQ869257 \\
Avu17 & 6 & $122-128$ & 0.27 & 0.28 & DQ869258 \\
Avu18 & 1 & 150 & - & - & DQ869259 \\
Avu25 & 25 & $214-277$ & 0.71 & 0.86 & DQ869261 \\
Avu26 & 34 & $226-299$ & 0.78 & 0.81 & DQ869247 \\
Avu27 & 3 & $208-253$ & 0.22 & 0.24 & NS \\
AspB01 & 1 & 169 & - & - & NS \\
AspB03 & 1 & $232-242$ & 0.06 & 0.06 & EU693332 \\
AspB05 & 18 & $159-295$ & 0.82 & 0.82 & EU693333 \\
AspB15 & 1 & 192 & - & - & EU693335 \\
AspB18 & 1 & 110 & - & - & EU693336 \\
\hline
\end{tabular}

From October 2008 to January 2009, twenty-five adult bonefish were implanted with AT tags. Individual data on fish sizes, release location, dates of release, days in study, minimum route distance traveled and day of last transmission are provided in Table 2. 
TABLE 2: Summary of acoustic telemetry data for 25 bonefish tagged between October 2008 and January 2009). The sex of 11 fish was identified during surgery ( 9 -female, $\widehat{D}$-male). Period detected is the time (days) in which tagged fish are detected by a receiver in the array. Days at large are the number of days fish went undetected. Distance represents distance traveled by each tagged fish, calculated by measuring the distance between receivers (assuming bonefish travel along the shoreline as anecdotal reports suggest). A * indicates that minimum route distance traveled was calculated as 0 because fish was only detected by one receiver, i.e. receiver at release location, but over several days. However, analysis of the dates and times of detections indicates that the detections are likely not a result of expelled pingers and fish traveled outside of array and time at large was $>48$ days.

\begin{tabular}{|c|c|c|c|c|c|c|c|c|}
\hline $\begin{array}{l}\text { Fish } \\
\text { ID }\end{array}$ & $\begin{array}{c}\text { FL } \\
(\mathbf{m m})\end{array}$ & $\begin{array}{l}\text { Date of } \\
\text { release }\end{array}$ & $\begin{array}{l}\text { Release } \\
\text { location }\end{array}$ & $\begin{array}{c}\text { Period } \\
\text { detected } \\
\text { (d) }\end{array}$ & $\begin{array}{c}\text { Days } \\
\text { at } \\
\text { large }\end{array}$ & $\begin{array}{c}\text { Distance } \\
\text { traveled } \\
(\mathbf{k m})\end{array}$ & $\begin{array}{c}\text { Last } \\
\text { detection }\end{array}$ & $\begin{array}{c}\text { Last } \\
\text { detected } \\
\text { at }\end{array}$ \\
\hline 12 & 358 & 29-Nov-08 & $\begin{array}{l}\text { North } \\
\text { Bight }\end{array}$ & 1 & 6 & 4 & 5-Dec-08 & $\begin{array}{l}\text { North } \\
\text { Bight }\end{array}$ \\
\hline 13 & 420 & $30-\mathrm{Nov}-08$ & $\begin{array}{l}\text { North } \\
\text { Bight }\end{array}$ & 3 & 2 & 20 & 4-Dec-08 & West \\
\hline 14 ㅇ & 450 & 3-Dec-08 & $\begin{array}{l}\text { North } \\
\text { Bight }\end{array}$ & 7 & 9 & 109 & 18-Dec-08 & West \\
\hline $15 q$ & 450 & 3-Dec-08 & $\begin{array}{l}\text { North } \\
\text { Bight }\end{array}$ & ND & ND & ND & ND & ND \\
\hline 17 & 420 & 29-Nov-08 & $\begin{array}{l}\text { North } \\
\text { Bight }\end{array}$ & 21 & 35 & 102 & 23-Jan-09 & West \\
\hline $18 ठ$ & 400 & 22-Jan-09 & $\begin{array}{l}\text { North } \\
\text { Bight }\end{array}$ & 5 & 197 & 20 & 11-Aug-09 & West \\
\hline 22 & 400 & 29-Nov-08 & $\begin{array}{l}\text { North } \\
\text { Bight }\end{array}$ & 2 & 1 & 20 & 1-Dec-08 & West \\
\hline $23 q$ & 500 & 3-Dec-08 & $\begin{array}{l}\text { North } \\
\text { Bight }\end{array}$ & 8 & 7 & 107 & 17-Dec-08 & West \\
\hline 24 & 425 & 28-Jan-09 & $\begin{array}{l}\text { North } \\
\text { Bight }\end{array}$ & 1 & 0 & 0 & 28-Jan-09 & $\begin{array}{l}\text { North } \\
\text { Bight }\end{array}$ \\
\hline 27 के & 400 & $31-$ - ct-08 & West & 10 & 9 & 121 & 18-Nov-08 & West \\
\hline 28 & 440 & 29-Nov-08 & $\begin{array}{l}\text { North } \\
\text { Bight }\end{array}$ & 39 & 210 & $0 *$ & 4-Aug-09 & $\begin{array}{l}\text { North } \\
\text { Bight }\end{array}$ \\
\hline 32 ठ & 500 & $11-$-Oct-08 & East & 15 & 288 & 217 & 9-Aug-09 & East \\
\hline $33 \hat{\sigma}$ & 475 & 11-Oct-08 & East & ND & ND & ND & ND & ND \\
\hline $34 \sigma^{\pi}$ & 405 & 30-Nov-08 & East & ND & ND & ND & ND & ND \\
\hline 36 & 450 & 29-Nov-08 & $\begin{array}{l}\text { North } \\
\text { Bight }\end{array}$ & 2 & 2 & 40 & 2-Dec-08 & West \\
\hline 37 & 545 & 5-Oct-08 & West & 1 & 3 & 25 & 8-Oct-08 & West \\
\hline $38 \sigma^{\pi}$ & 475 & $11-$-Oct-08 & East & 1 & 0 & 0 & $11-$-Oct-08 & East \\
\hline 39 & 415 & 9-Oct-08 & West & 115 & 158 & 15 & 8-Jul-09 & West \\
\hline 40 & 474 & 7-Oct-08 & West & ND & ND & ND & ND & ND \\
\hline 41 & 444 & 6-Oct-08 & West & 30 & 48 & $0 *$ & 22-Dec-08 & West \\
\hline 42 & 548 & $3-$ Oct-08 & West & 60 & 245 & $0^{*}$ & 3-Aug-09 & West \\
\hline 43 & 505 & 5-Oct-08 & West & 4 & 79 & $0^{*}$ & 26-Dec-08 & West \\
\hline 44 & 450 & 5-Oct-08 & West & ND & ND & ND & ND & ND \\
\hline 45 م & 492 & 6-Oct- 08 & West & 14 & 10 & 70 & 29-Oct-08 & East \\
\hline $46 \sigma^{\lambda}$ & 478 & 6-Oct-08 & West & 48 & 62 & 300 & 23-Jan-09 & West \\
\hline
\end{tabular}


Of the 25 fish tagged, 20 ( $80 \%$ ) of these were detected at least once. The number of days detected in the array was not correlated to the minimum distance traveled $\left(\mathrm{r}^{2}=0.002, \mathrm{p}\right.$-value $\left.=0.84\right)$. For example, fish \# 14 was detected in the array for just 7 days, but traveled $109 \mathrm{~km}$. Fish \# 39 was in the array for 115 days and was always detected by the same receiver. The latter fish was one of the smallest fish $(415 \mathrm{~mm})$ and was not noted as being sexually mature during surgery.

Of the twenty fish detected, seven traveled relatively long distances from the release location to the east side (i.e., at least $100 \mathrm{~km}$ ). Fish that traveled $>200 \mathrm{~km}$ were those that made multiple trips from the west to east side of Andros (see Table 2). For example, \# 46 was tagged at Wide Opening and detected as AUTEC Shallow receiver, detected at Little Loggerhead Creek (West Side), again at AUTEC Shallow and then again at Wide Opening. Six of the seven fish that exhibited this long distance movement were noted to be sexually mature (i.e. presence of eggs or milt) during surgery. Of the twenty-five fish tagged, I was able to determine the sex of only eleven during surgery. Three were identified as mature females and eight as mature males. All fish that made the long distance movements utilized the north bight as a corridor to migrate from the shallow flats on the west side to deeper waters on the east (Fig. 5). Of these seven fish, two made multiple trips to the east side (e.g. \# 32 in October 08, December 08 and August 09 and \# 46 in October 08 and December - January 09, see Figs. 7 \& 6 respectively). No further large-scale movement to the east side was detected after January 09 (with the exception of \# 32) (Fig. 7). 


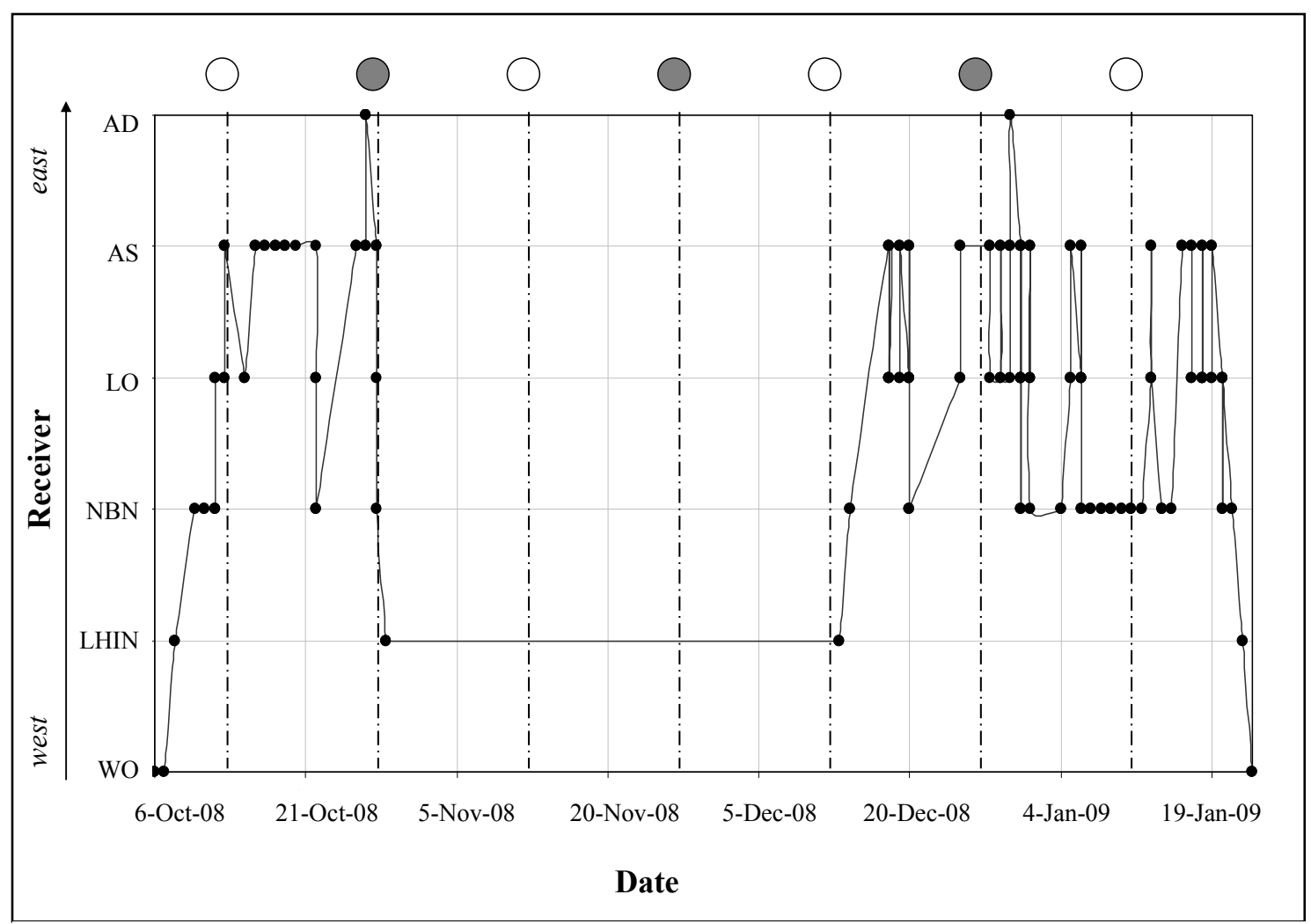

FIGURE 6: Bonefish movements assessed by acoustic telemetry results for fish \#46 in October 2008, showing movement from the west side to the east side during October and January. The fish made two distinct migrations from the west to east side of the island during the study period. Movement to reef receiver (coded "AD" at a depth of $\sim 6 \mathrm{~m}$ ) is observed around new moons (closed circle) in October and December. Receiver abbreviations from Figure 5. Each point in the figure represents a single detection by a receiver.

Tagged bonefish were detected on the east side from October 10 - October 28, 2008; November 11 - November 17, 2008; December 10 - January 21, 2009 and August 3 - August 9, 2009 (Fig. 7). No fish were detected on the east side between February 08 and August 09 (all receivers on the east side were in operation at final download in August 09). Movements as detected by east side receivers suggest lunar periodicity. Tagged fish were detected on reef receivers $(6-18 \mathrm{~m})$, at night, $1-2$ days before new moon in October, 3 days after the new moon in December, and 2 days before the full moon in November (Figs. 6 \& 8). Two fish tagged earlier in the study (ID\# 45 and \#46) 
appeared to be traveling together to the off-shore reef receivers around the new moon in October (Fig. 8).

On east Andros, fish displayed daily movement patterns where shallow flats $<1 \mathrm{~m}$ (LO in Fig. 5) were occupied in early morning and late evening hours and deeper channels $\sim 2.4$ m were occupied (AS in Fig. 5) during the afternoon. These daily patterns continued around the new and full moon where bonefish remained outside the range of receivers or were detected at off-shore reef receivers at night. The location AS on the east side of Andros is an area where large schools of bonefish were observed aggregating. Very large schools of bonefish $(\sim 300-500)$ were observed at AS on November 27, 2008 (i.e. on the new moon) and January 21, 2009 (i.e. 5 days before the new moon). The fish observed on November 27, 2008 were on/near the surface, unresponsive to anglers and occasionally bumping into the boat. Anglers reported seeing a large school of bonefish ( $\sim 300$ individuals) offshore from the AS receiver in fifteen meters of water on November $26^{\text {th }}, 2008$ (i.e. one day before the new moon). 


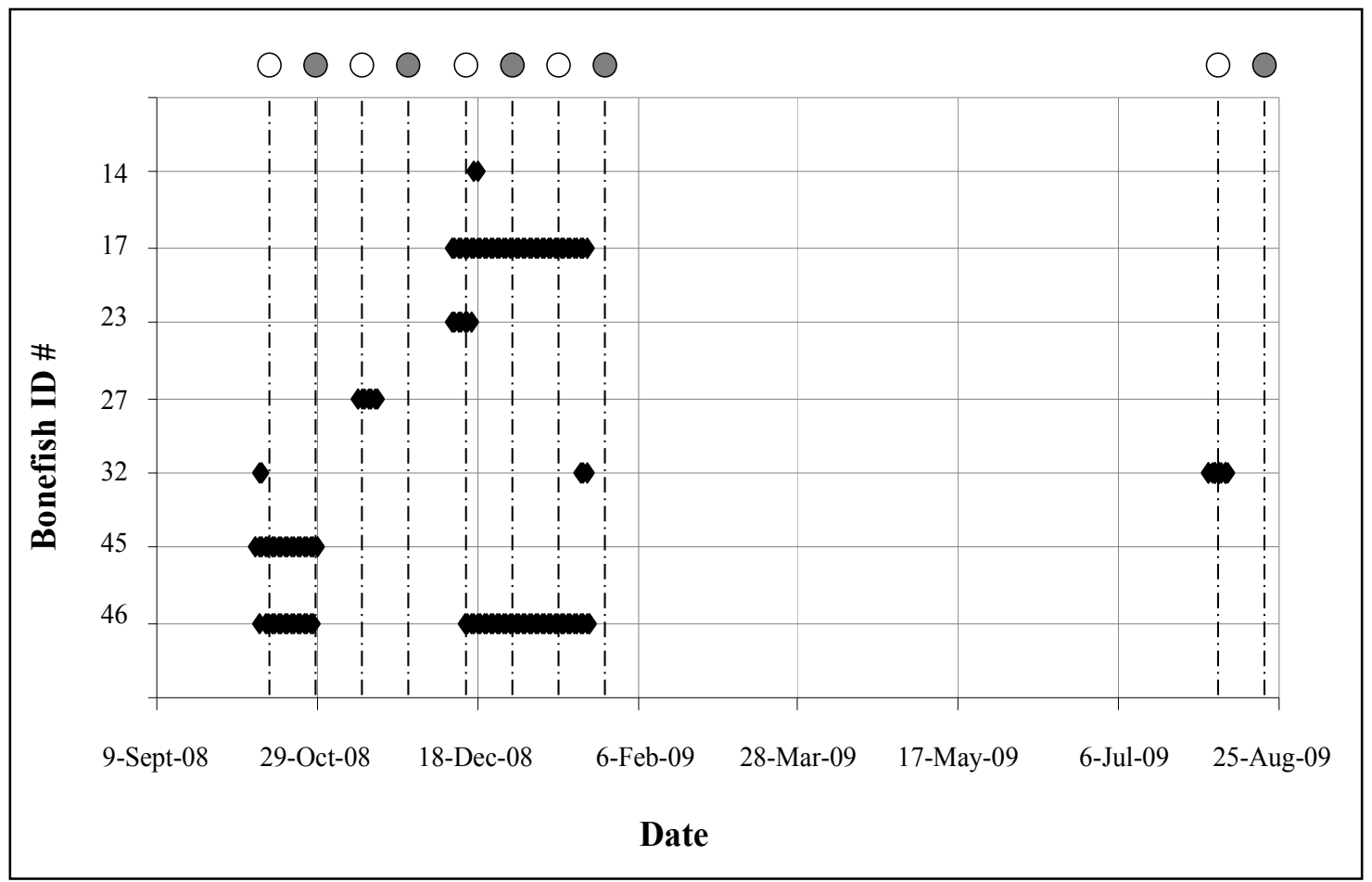

FIGURE 7: Bonefish detections on east side receivers (i.e. receivers coded NBN, NBS, LO, AS, AD, NBR or MB). After traveling from west side, bonefish are detected on the east side for both new moons (closed circles) and full moons (open circles). No fish were detected on the east side during Feb 08 and August 09 even though all receivers were in operation through August 09. Fish IDs 45 and 46 were tagged at WO on October 6, 2008. Fish ID 32 was tagged at AS on October 11, 2008. Fish ID 27 was tagged at WO on October 31, 2008. Fish ID's 23 and 17 were tagged at BC on December 3 and November 29, 2008 respectively. Fish ID 14 was tagged at BC on December 3, 2008. See Figure 5 for receiver and tagging locations. 


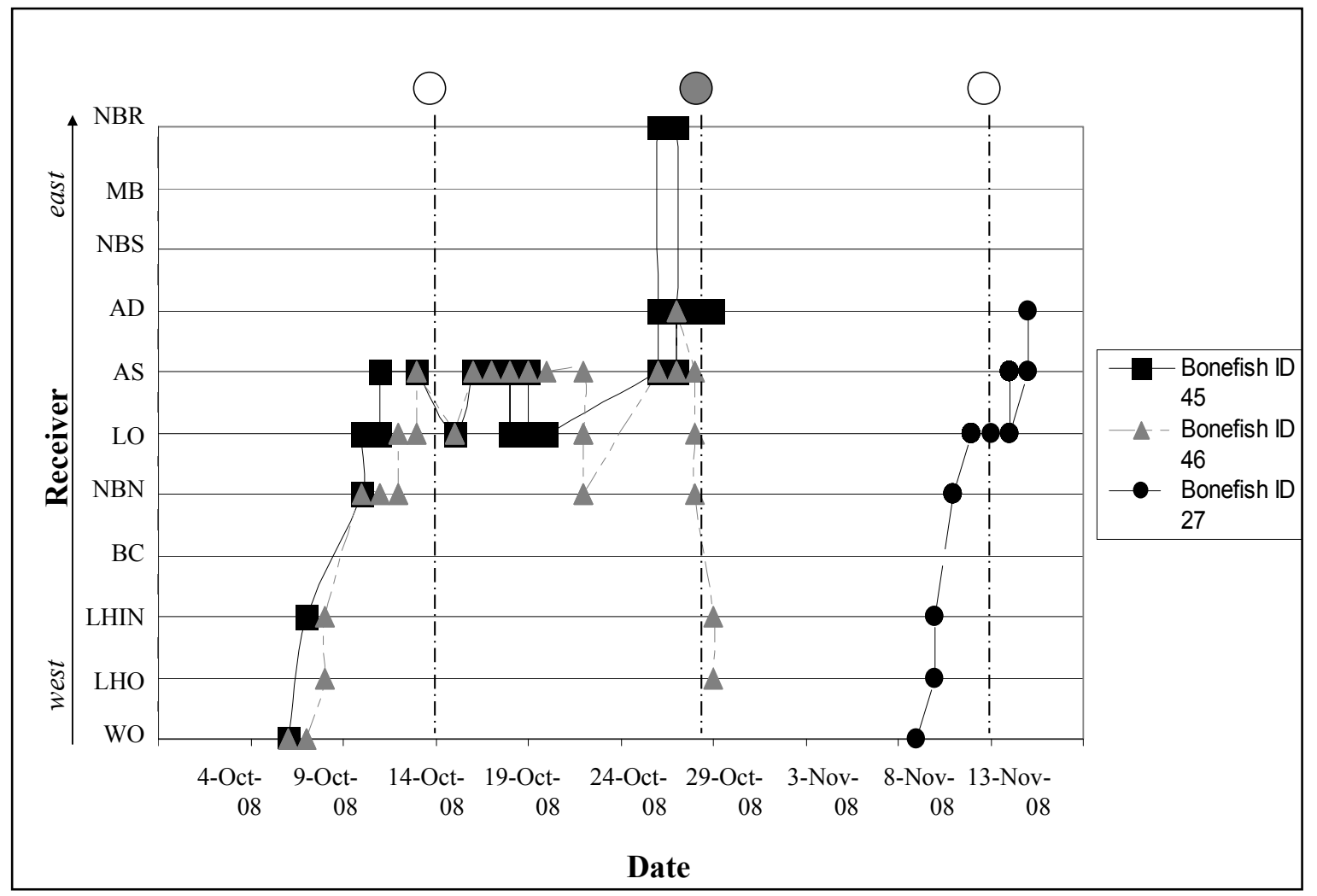

FIGURE 8: Bonefish acoustic telemetry results for three fish (ID's 27, 45 \& 46) tagged in October \& November 2008, showing movement from the west side to the east side during October \& November. Fish ID\# $45 \& 46$ shows schooling behavior. Movement to reef receivers (AD at $\sim 6 \mathrm{~m}$ depth and NBR at $\sim 18 \mathrm{~m}$ ) was observed around the new moon (closed circle) in October and full moon (open circle) in November. Each point in the figure represents a single detection by a receiver. Receiver abbreviations from Figure 5.

\section{DISCUSSION}

Large-scale movements (i.e., $>100 \mathrm{~km}$ from west to east) were observed between mid-October and the end of January. Two fish (ID \# 32 and \# 46) made multiple trips to the east side traveling a total round trip (minimum) distance of at least $217 \mathrm{~km}$ and 300 $\mathrm{km}$ respectively. Such large-scale movements to presumed spawning sites are the first to be documented. The majority of the fish that made these large-scale movements were noted to be mature and hence may indicate the peak spawning time (October - January) around Andros. Tagged fish utilized the North Bight as an important migration corridor during such large-scale movements. 
Although North Bight was identified as an important migration corridor for bonefish, a closer look at the movement patterns of several fish suggest that bonefish may also use alternate routes or a route that placed them outside the receiver detection range. For example, fish \#32 in the study was detected on the west side of Andros on January 23, 2008 and detected again on the east side August 3, 2009. There were no detections by receivers located within North Bight between the west and east side detections. All receivers were in operation throughout the study period, so the lack of detections was not attributed to faulty receivers. In addition, the absence of several fish (e.g. \#’s $32 \& 42$ ) and a subsequent reappearance after $\sim 6$ months may suggest that bonefish travel much further than anticipated or may use multiple spawning sites during the spawning season.

Lunar periodicity of offshore movements suggests these movements were associated with spawning. Offshore movement (i.e. at receivers $6-18 \mathrm{~m}$ deep) was observed in October, November and December and coincided with either the full or new moon. In addition, although off-shore movements were mainly observed around new moons, there were times when fish were completely missing from the array around the full moons which may indicate other spawning sites not covered by the array. Such lunar spawning rhythms are common for tropical marine species and may maximize dispersal of fertilized eggs (Johannes 1978). This offshore movement is usually observed during dusk with a return to shallower waters during dawn of the following morning. For example, fish 45 was detected moving offshore two days before the new moon in October at 21:19 at receiver in $6 \mathrm{~m}$ depth, and not detected again until that following morning at 02:39 at an $18 \mathrm{~m}$ depth receiver (see Fig. 8). Nocturnal spawning behavior is common for species with pelagic eggs (Johannes 1978). Such a spawning strategy may minimize egg 
predation or may reduce the threat of predation on the spawners themselves (Johannes 1978).

To the extent that these data indicate spawning periodicity, findings from this study differ with other studies and observations of peak spawning periods. A study conducted in the Florida Keys, for example, reported detection of five large mature bonefish Albula sp., at receivers located in water depths of about $20 \mathrm{~m}$ (Larkin et al. 2008). The observed offshore movement occurred between March and May 2004, and may have been bonefish in spawning migrations because those fish were generally well above the minimum size of sexual maturity $(1.8 \mathrm{~kg} / 48 \mathrm{~cm})$, and moved during peak reproductive months (Crabtree et al. 1997, Larkin et al. 2008). Studies in Eleuthera (an island to the southeast of Andros) have shown similar patterns in Albula spp. movement presumably associated with spawning. Increased bonefish movement was observed during September - January with offshore movement occurring around the new moon between February and March and also during the full moon in June (Andy DanylchukUniversity of Massachusetts - Amherst, personal communication). In addition, during March 21 - April 2, 2008, nine bonefish tagged in Eleuthera were all detected at the same receiver located at a depth of about $27 \mathrm{~m}$ (Andy Danylchuk, personal communication).

My data correspond with observations of spawning behavior of bonefish in aquarium tanks at the Atlantis Resort (Nassau, Bahamas). These are open air tanks ( 13 $m$ deep) and are therefore open to the natural elements, with salt water pumped directly from a lagoon every two hours. The tanks contain a variety of fish species including approximately 250 bonefish. Bonefish spawning behavior was observed during dawn (06:30) one day after the full moon in October, one to four days before the full moon in 
November 08 , December 08 and January 09 . Spawning behaviors included tightly packed schools (about 20 - 30 fish) near the surface of the water and males nudging females in violent swimming motions. There was also a report of male and female gametes suspended in the water column following such behavior (Dave Wert - Atlantis Resort, personal communication).

In conclusion, bonefish travel long distances from shallow flats to pre-spawning aggregation sites in proximity to off-shore spawning locations. Off-shore movement occur around both new and full moons. However, it is yet to be confirmed, through direct observation, if spawning is occurring at these off-shore reef locations. This study has also confirmed anecdotal reports that the North Bight is an important spawning migration corridor for bonefish, specifically the North Bight shoreline. This information is critical for the protection of bonefish and identifies important habitats (e.g. migration corridors and pre-spawning aggregations) on Andros that warrants protection from coastal degradation or fishing pressure. In addition, considering that bonefish supports a smallscale subsistence fishery in The Bahamas, peak spawning times identified could suggest a time for closed seasons where the harvest of bonefish is prohibited. 


\section{LITERATURE CITED}

Acosta, C.A. 1999. Benthic dispersal of Caribbean spiny lobsters among insular habitats: Implications for the conservation of exploited marine species. Conservation Biology 13: 603-612.

Adams, A.J., R.K. Wolfe, M.D. Tringali, E.M. Wallace \& G.T. Kellison. 2008. Rethinking the status of Albula spp. biology in the Caribbean and Western Atlantic. pp. 203-214. In: J.S. Ault (ed.) Biology and management of the world tarpon and bonefish fisheries, CRC Press, Boca Raton, FL.

Afonso, P., J. Fontes, K.N. Holland \& R.S. Santos. 2009. Multi-scale patterns of habitat use in a highly mobile reef fish, the white trevally Pseudocaranx dentex, and their implications for marine reserve design. Marine Ecology-Progress Series 381: 273286.

Ault, J.S., R. Humston, M.F. Larkin, E. Perusquia, N.A. Farmer, J. Luo, N. Zurcher, S.G. Smith, L.R. Barbieri \& J.M. Posada. 2008. Population dynamics and resource ecology of Atlantic tarpon and bonefish. pp. 217-258. In: J.S. Ault (ed.) Biology and management of the world tarpon and bonefish fisheries, CRC Press, Boca Raton, FL.

Belkhir, K., Borsa, P., Chikhi, L., Raufaste, N., Bonhomme, F. (2000). GENETIX, logiciel sous WindowsTM pour la génétique des populations. Laboratoire Génome, Populations, Interactions CNRS UMR 5000, Université de Montpellier II, Montpellier, France.

Botsford, L.W., A. Hastings \& S.D. Gaines. 2001. Dependence of sustainability on the configuration of marine reserves and larval dispersal distance. Ecology Letters 4: 144-150.

Bowen, B.W., Karl S.K. and Pfeiler E. 2008. Resolving Evolutionary Lineages and Taxonomy of Bonefishes (Albula spp.). pp. 147-154. In: J.S. Ault (ed.) Biology and Management of the World Tarpon and Bonefish Fisheries, CRC Press, Boca Raton, FL.

Colborn, J., R.E. Crabtree, J.B. Shaklee, E. Pfeiler \& B.W. Bowen. 2001. The evolutionary enigma of bonefishes (Albula spp.): Cryptic species and ancient separations in a globally distributed shorefish. Evolution 55: 807-820.

Crabtree, R.E., D. Snodgrass \& C.W. Harnden. 1997. Maturation and reproductive seasonality in bonefish, Albula vulpes, from the waters of the Florida Keys. Fishery Bulletin 95: 456-465. 
Humston, R., J.S. Ault, M.F. Larkin \& J.G. Luo. 2005. Movements and site fidelity of the bonefish Albula vulpes in the northern Florida Keys determined by acoustic telemetry. Marine Ecology-Progress Series 291: 237-248.

Johannes, R.E. 1978. Reproductive strategies of coastal marine fishes in the tropics. Environmental Biology of Fishes 3: 65-84.

Kramer, D.L. \& M.R. Chapman. 1999. Implications of fish home range size and relocation for marine reserve function. Environmental Biology of Fishes 55: 6579.

Larkin, M.F., J.S. Ault, R. Humston, J. Luo \& N. Zurcher. 2008. Tagging of Bonefish in South Florida to Study Population Movements and Stock Dynamics. In: J.S. Ault (ed.) Biology and Management of the World Tarpon and Bonefish Fisheries, CRC Press, Boca Raton, FL.

Lunt, D.H., W.F. Hutchinson \& G.R. Carvalho. 1999. An efficient method for PCR-based isolation of microsatellite arrays (PIMA). Molecular Ecology 8: 891-893.

Morgan, S.G. \& J.H. Christy. 1994. Plasticity, constraint, and optimality in reproductive timing. Ecology 75: 2185-2203.

Norcross, B.L. \& R.F. Shaw. 1984. Oceanic and estuarine transport of fish eggs and larvae - a review. Transactions of the American Fisheries Society 113: 153-165.

Pfeiler, E. 2008. Resurrection of the name Albula pacifica (Beebe, 1942) for the shafted bonefish (Albuliformes: Albulidae) from the eastern Pacific. Revista De Biologia Tropical 56: 839-844.

Pittman, S.J. \& C.A. McAlpine. 2003. Movement of Marine Fish and Decapod Crustaceans: Process, Theory and Application. Advances in Marine Biology: 205294.

Rapid Ecological Assessment West Coast of Andros, T.B. 2006. pp. 127 REA Report, The Nature Conservancy, Nassau, Bahamas.

Ray, C.G. \& J. McCormick. 2004. Coastal-marine conservation: science and policy. Blackwell Publishing, Malden, MA. 327 pp.

Raymond M. \& Rousset F, 1995. GENEPOP (version 1.2): population genetics software for exact tests and ecumenicism. J. Heredity, 86:248-249.

Rice, W.R. 1989. Analyzing tables of statistical tests. Evolution 43: 223-225. 
Roberts, C.M. \& H. Sargant. 2002. Fishery benefits of fully protected marine reserves: why habitat and behavior are important. Natural Resource Model 15: 487-507.

Seyoum, S., E.M. Wallace \& M.D. Tringali. 2008. Twelve polymorphic microsatellite markers for the bonefish, Albula vulpes and two congeners. Molecular Ecology Resources 8: 354-356.

Warner, R.R., S.E. Swearer \& J.E. Caselle. 2000. Larval accumulation and retention: Implications for the design of marine reserves and essential fish habitat. pp. 821830. 


\section{Chapter III}

\section{The Future of Bonefish Conservation and Management in The Bahamas}

\section{INTRODUCTION}

The advent of bonefish as a recreational fishery in The Bahamas has made the clear, relatively pristine shallow flats of the islands a primary fly-fishing destination for anglers worldwide. What was once important for local consumption has now been transformed into a multi-million dollar tourism industry. For example, exit surveys, conducted by the Ministry of Tourism in 2007 , revealed that $55 \%$ of visitors to Andros (the largest island in The Bahamas) chose that destination primarily because of the sporting attractions (e.g., bonefishing, snorkeling and diving). With an average expenditure of $\$ 1,900$ per visitor, the estimated income generated from the sporting activities totaled \$9.8 million for 2007 (Andros Exit Survey Report 2007).

Undoubtedly, most would agree that the bonefish industry is economically important for many coastal communities. However, the growing popularity of the industry, and concerns for rapid human population growth, may threaten bonefish populations and a quality-fishing experience. Such negative impacts include an increase in fishing pressures and concomitant increase in incidental mortality, local shoreline development, habitat degradation, and the loss of spawning and nursery areas (Tilmant 2008). Despite gaps in our knowledge of bonefish biology, it is imperative that we move forward with the best science available to make informed decisions for the conservation and management of the species. An adaptive management approach would allow for optimal decision making when there is uncertainty, and to guide ongoing and future 
research. Such an approach will simultaneously maximize management objectives while accruing information needed to improve future management.

\section{National Park Protection}

The Bahamas National Trust (BNT) was established by an Act of Parliament in 1959. It is a non-governmental, non-profit organization mandated with the development and management of the National Park System in The Bahamas. It is the only nongovernmental organization in the world to be charged with this responsibility. Over the past half century the Trust has developed a system of 25 parks and protected areas throughout the 700 islands of The Bahamas comprising a total of more than 700,000 acres (The Bahamas National Trust 2008a). The Trust collaborates with other agencies like The Nature Conservancy, the Department of Marine Resources and The Bahamas Environment Science and Technology Commission to achieve national conservation goals. The Bahamas is committed to a Program of Work on Protected Areas that was adopted by the United Nations Convention on Biological Diversity. This program includes the development of a master plan to conserve an additional 10 percent of critical terrestrial habitat by 2012 and 20 percent of near shore marine resources by 2020 (The Bahamas National Trust 2008b).

As government agencies and local conservation organizations realize the value of the bonefish fishery, these parties are in need of scientific information to make informed decisions to manage and protect the fishery. At present, efforts are being made to identify priority sites for conservation of a large area on the western side of Andros, Bahamas. A Rapid Ecological Assessment (REA) was conducted in 2006, which, in combination with 
stakeholder input, will form the basis for a proposal to the government of The Bahamas for the expansion of existing park boundaries (Adams 2006). The REA recommended that a large-scale habitat conservation strategy is required to ensure the long-term sustainability of West Andros bonefish (Friedlander et al. 2008).

In the past, most investigations into Marine Protected Area (MPA) design have focused on determining the optimal size or spatial arrangement of MPA's. However, key to determining appropriate size and location of an MPA is information on movement patterns of key species and hence identify which habitat types or key areas (e.g. essential nursery areas or spawning areas) are necessary to include in the design (Botsford et al. 2001). In the case of highly mobile species, unless MPA's are large enough to include all habitats and migration corridors, these MPA's will only offer protection on a partial or seasonal basis (Afonso et al. 2009). But if MPA's were to include important spawning sites and movement corridors, they still could play a vital role in fishery management (Kramer \& Chapman 1999, Roberts \& Sargant 2002, Afonso et al. 2009).

Conservation priority sites identified from this study include North Bight and a pre-spawning aggregation identified on the east side (coded as AS) (Fig. 5). These areas represent critical habitats for bonefish. However, movement data and anecdotal reports suggest that there may be multiple pre-spawning aggregation sites located on the east side and possibly additional migration pathways. Additional studies are required to identify such areas.

Bahamas National Trusts' vision is to develop “a comprehensive system of national parks and protected areas, with every Bahamian embracing environmental stewardship". This translates to residents playing an integral role in the design, 
management and recreational use of all National Parks throughout The Bahamas. In the past, most National Parks in The Bahamas that include marine environs have been designated as no-take zones, i.e., areas in which extraction of constituent organisms are not permitted. However, urban development and the need to create spaces for recreational use have changed the way we think and the regulations that are imposed on these areas. It requires a delicate balance and a multi-user approach.

In carrying out its mandate to conserve and protect the natural resources of The Bahamas, it is important that The Bahamas National Trust allows for sustainable catchand-release practices. When properly managed, recreational fishing can be an appropriate and compatible use for National Park Systems (Tilmant 2008). Therefore, although critical nursery areas may be zoned for no coastal development and spawning aggregation sites designated as "no-take" areas, there must also be consideration for the impacts that anglers have on the resources. With Andros being identified as "the bonefishing capital of the world", regulations should be set that minimize these impacts and allow for activities that will not jeopardize the future existence of the resources. Decisions should me made regarding appropriate visitor activities, the sustainable development of lodges and visitor centers, suitable levels of boating traffic and proper catch-and-release handling practices. These management practices will not only protect the national resources of The Bahamas but also preserve the solitude of the fly-fishing experience.

\section{Protection Through Fisheries Regulations}

The responsibilities of the Ministry of Agriculture and Marine Resources in relation to the marine resources of The Bahamas are to: (1) promote the growth of 
fisheries under the principles of sustainable use and integrated management; and (2) implement fisheries and development objectives (Bahamas Environment Science and Technology Commission 2002). In regards to the subsistence fishing of bonefish in The Bahamas, there are currently only two regulations in place regarding the harvesting of bonefish: (1) the use of monofilament gill nets (known locally as "hauling") is prohibited and (2) the selling or purchasing of bonefish is prohibited (Bahamas Department of Marine Resources 1986). However, just recently, considerations are being made by the ministry to set new regulations regarding the harvesting of bonefish which include: (1) the establishment of maximum and minimum size limits; and (2) implementing a bag limit.

Suggestions for future considerations include: (1) making the fishery catch-andrelease only during spawning months; and (2) requiring guides to obtain special flyfishing licenses. Such licenses can regulate the activities of the guides and anglers through the adoption of the best practices for bonefish catch-and-release to ensure postrelease survival. Best practices include the use of barbless hooks, using the appropriate tackle to ensure quick landing, minimizing handling time and releasing bonefish in areas with low shark abundance (Cooke \& Philipp 2004).

\section{Looking Ahead to the Future}

The future of the bonefish industry in The Bahamas is a promising one. Many new initiatives regarding this economically important fishery have taken off within the past year on many different levels e.g., by both the government and local community. The Ministry of Tourism is in the process of developing a bonefish guide certification 
program. In addition, a collaboration initiated in 2009 between the Bahamas National Trust, Bonefish Tarpon and Trust and the Fisheries Conservation Foundation has formed the Bahamas Flats Fishing Alliance (BFFA). Among others, a few of the goals of the collaboration are to: (1) identify key scientific information and research needs relevant to Bahamian flats fisheries and ecosystems; (2) encourage fisheries scientists and managers to conduct new research, education, and outreach programs; and (3) develop tools to communicate relevant scientific information to decision makers and the public. Through this collaboration, The Bahamas Initiative was developed. The objectives are: (1) collect basic natural history information on bonefish, including species identity, age-growth, and movement patterns; (2) coordinate and conduct bonefish conservation and education efforts throughout The Bahamas; and (3) develop a Bahamas Bonefish Research and Conservation Webpage to facilitate communication, education, and sharing of program results.

The future of the bonefish industry will ultimately lie in the hands of the guide, angler and manager. The programs above acknowledge this very important relationship. By working together through co-coordinated efforts we will move the industry forward and promote a sustainable fishery. 


\section{LITERATURE CITED}

Adams, A.J. 2006. Rapid Ecological Assessment West Coast of Andros, The Bahamas: Preliminary report of scientific findings, The Nature Conservancy, Nassau, Bahamas.

Afonso, P., J. Fontes, K.N. Holland \& R.S. Santos. 2009. Multi-scale patterns of habitat use in a highly mobile reef fish, the white trevally Pseudocaranx dentex, and their implications for marine reserve design. Marine Ecology-Progress Series 381: 273 286.

Bahamas Environment Science and Technology Commission. 2002. Bahamas Environmental Handbook. pp. 1-118, The Government of The Bahamas, Nassau.

Botsford, L.W., A. Hastings \& S.D. Gaines. 2001. Dependence of sustainability on the configuration of marine reserves and larval dispersal distance. Ecology Letters 4: 144-150.

Cooke, S.J. \& D.P. Philipp. 2004. Behavior and mortality of caught-and-released bonefish (Albula spp.) in Bahamian waters with implications for a sustainable recreational fishery. Biological Conservation 118: 599-607.

Friedlander, A.M., J.E. Caselle, J. Beets, C.G. Lowe, B.W. Bowen, T.K. Ogawa, K.M. Kelley, T. Calitri, M. Lange \& B.S. Anderson. 2008. Biology and ecology of the recreational bonefish fishery at Palmyra Atoll National Wildlife Refuge with comparisons to other Pacific Islands. pp. 27-56. In: J.S. Ault (ed.) Biology and management of the world tarpon and bonefish fisheries, CRC Press, Boca Raton, FL.

Kramer, D.L. \& M.R. Chapman. 1999. Implications of fish home range size and relocation for marine reserve function. Environmental Biology of Fishes 55: 6579.

Andros Exit Survey Report. 2007. pp. 42, Ministry of Tourism, Nassau.

Bahamas Department of Marine Resources. 1986. Bahamian Fisheries Regulations and Reports.

Roberts, C.M. \& H. Sargant. 2002. Fishery Benefits of Fully Protected Marine Reserves: Why Habitat and Behavior are Important. Natural Resource Model 15: 487-507.

Tilmant, J.T. 2008. National Parks and the Conservation of Bonefish and Tarpon Fisheries. pp. 351-358. In: J.S. Ault (ed.) Biology and Management of the World Tarpon and Bonefish Fisheries, CRC Press, Boca Raton, FL. 
The Bahamas National Trust. 2008a. National Park - National Treasures, Nassau.

The Bahamas National Trust. 2008b. Strategic Plan 2008-2013, The Bahamas National Trust, Nassau. 